\title{
AГPAPMA EROMOMDRA
}

УДК: 657

https://doi.org/10.31470/2306-546X-2019-40-07-13

\section{ЧИННИКИ ВИКОРИСТАННЯ ТРУДОВОГО І ВИРОБНИЧОГО ПОТЕНЦІАЛУ ФЕРМЕРСЬКИХ ТА ОСОБИСТИХ ГОСПОДАРСТВ НАСЕЛЕННЯ Й УПРАВЛІННЯ ЙОГО РОЗВИТКОМ}

Ігнатенко М. М.

Предметом дослідження є процеси формування та використання трудового й виробничого потенціалу фермерських $і$ особистих господарств населення, управління його удосконаленням $i$ розвитком.

Метою роботи є виявлення чинників формування і рівня та використання трудового й виробничого потенціалу фермерських та особистих господарств населення, а також обгрунтування на цій основі напрямів його удосконалення й управління розвитком на перспективу.

Методологічною основою статmі стали як загальнонаукові, так і спеціальні методи наукового пізнання. У сукупності перших - це абстрактно-логічний, діалектичний, монографічний, системноструктурного аналізу і синтезу. Серед спеціальних методів були використані статистико-економічні методи (абсолютних і відносних величин, групування, порівняння), економіко-математичні (індексний), опитування, моделювання.

Результати роботи. Обгрунтовано пріоритетне значення трудового й виробничого потенціалу у розвитку фермерських та особистих господарств населення. Визначено стан їх забезпечення матеріально-технічними засобами. Виявлено рівень використання трудових ресурсів. Обгрунтовано чинники формування складових ресурсного потенціалу фрермерських $і$ особистих господарств. Визначено проблеми й тенденції розвитку трудового й виробничого потенціалу на рівні вказаних малих форм аграрного господарювання та управління ним. Розроблено напрями та джерела його удосконалення на перспективу.

Галузь застосування результатів. Теоретичні висновки та результати дослідження можуть бути застосовані при викладанні економічних дисциплін в університетах при підготовці фрахівців 3 організації виробництва, менеджменту, економіки та управління. Практичні пропозиції доцільно використовувати в удосконаленні матеріально-технічного й трудоресурсного забезпечення фермерських та особистих господарств населення, в організації та розвитку сільських територій.

Висновки. У сучасному селі жителі працюють у фрермерських та особистих селянських господарствах для забезпечення продовольчих потреб власної родини й додаткових грошових доходів. Для підвищення їх продуктивності необхідним вважаємо удосконалення виробничого й трудового потенціалу. Також велике значення має підтримка та розвиток сочіальної та виробничої інфраструктури, альтернативних видів зайнятості, сільських територій загалом. Цьому сприяє діяльність сільських територіальних громад, інших заходів адміністративно-територіальної реформи на селі.

Ключові слова: фрермерські й особисті селянські господарства, виробничий і трудовий потенціал, чинники, формування, використання, ефрективність, управління, розвиток. 


\section{ФАКТОРЫ ИСПОЛЬЗОВАНИЯ ТРУДОВОГО И ПРОИЗВОДСТВЕННОГО ПОТЕНЦИАЛА ФЕРМЕРСКИХ И ЛИЧНЫХ ХОЗЯЙСТВ НАСЕЛЕНИЯ И УПРАВЛЕНИЕ ЕГО РАЗВИТИЕМ} $\begin{aligned} & \text { Игнатенко Н. Н. } \\ & \text { Предметом исследования являются процессы формирования и использования трудового } и \\ & \text { производственного потенциала фрермерских u личных хозяйств населения, управления его }\end{aligned}$ совершенствованием и развитием.

Целью работы является выявление фракторов формирования и уровня и использования трудового и производственного потенциала фермерских и личных хозяйств населения, а также обоснование на этой основе направлений его совершенствования и управления развитием на перспективу.

Методологической основой статьи стали как общенаучные, так и специальные методы научного познания. В совокупности первых - это абстрактно-логический, диалектический, монографический, системно-структурного анализа и синтеза. Среди специальных методов были использованы статистико-экономические методы (абсолютных и относительных величин, группировки, сравнения), экономико-математические (индексный), опрос, моделирование.

Результаты работы. Обоснованно приоритетное значение трудового и производственного потенциала в развитии фермерских и личных хозяйств населения. Определено состояние их обеспечения материально-техническими средствами. Выявлен уровень использования трудовых ресурсов. Обоснованно фракторы фрормирования составляющих ресурсного потенциала фрермерских и личных хозяйств. Определены проблемы и тенденции развития трудового и производственного потенциала на уровне указанных малых фрорм аграрного хозяйствования и управления им. Разработаны направления и источники его совершенствования на перспективу.

Область применения результатов. Теоретические выводы и результаты исследования могут быть применены при преподавании экономических дисциплин в университетах при подготовке специалистов по организации производства, менеджмента, экономики и управления. Практические предложения целесообразно использовать в совершенствовании материально-технического и трудоресурсного обеспечения фрермерских и личных хозяйств населения, в организации и развития сельских территорий.

Выводы. В современном селе жители работают в фермерских и личных крестьянских хозяйствах для обеспечения продовольственных нужд собственной семьи и дополнительных денежных доходов. Для повышения их производительности необходимым считаем усовершенствования производственного и трудового потенциала. Также большое значение имеет поддержка и развитие социальной и производственной инфраструктуры, альтернативных видов занятости, сельских территорий в целом. Этому способствует деятельность сельских территориальных общин, других мер административно-территориальной реформы на селе.

Ключевые слова: фермерские и личные крестьянские хозяйства, производственный и трудовой потенциал, фракторы, формирования, использования, эффективность, управление, развитие.

\section{FACTORS OF THE USE OF LABOUR AND PRODUCTION POTENTIAL OF FARMS AND PRIVATE HOUSEHOLDS AND MANAGEMENT OF ITS DEVELOPMENT}

Ignatenko M. M.

The subject of the research is the processes of formation and use of labor and production potential of farm and private households of the population, management of its improvement and development.

The purpose of the work is to identify the factors of formation and level and use of labor and production potential of farmers and private households of the population, as well as the justification on this basis of directions for its improvement and development management for the future.

Methodological basis of the article became as general scientific, and special methods of scientific knowledge. In the aggregate of the first - it is abstract-logical, dialectical, monographic, system-structural analysis and synthesis. Among the special methods were used statistical and economic methods (absolute and relative values, grouping, comparison), economic-mathematical (index), survey, modeling.

Results of work. The priority value of labor and production potential in the development of farmers' and private households is substantiated. The state of their provision by material and technical means is determined. The level of use of labor resources is revealed. The factors of formation of components of resource potential of farms and private farms are substantiated. The problems and tendencies of development of labor and production potential at the level of the mentioned small forms of agrarian management and management are determined. Directions and sources of its improvement for the future are developed.

The field of application of results. Theoretical conclusions and research results can be applied at the teaching of economic disciplines at universities in the training of specialists in the organization of production, management, economics and management. It is advisable to use practical proposals in improving the material and technical and labor supply of farm and private households, in the organization and development of rural areas.

Conclusions. In a modern village, residents work in farmers' and private farms to meet the food needs of their own family and additional cash incomes. To improve their productivity, we consider it necessary to improve the 
production and labor potential. Support and development of social and industrial infrastructure, alternative types of employment, and rural areas as a whole are also of great importance. This is facilitated by the activities of rural communities, other measures of administrative and territorial reform in the countryside.

Key words: farm and personal peasant farms, production and labor potential, factors, formation, use, efficiency, management, development.

JEL Classification: L23, J21, J43

Постановка проблеми. Розвиток фермерських та особистих господарств населення має виняткове значення у виробництві продуктів харчування, є основою формування середнього класу на селі, підтримки сільського способу життя й сільських територій. Тому створення та використання їх трудового й виробничого потенціалу, а також дослідження цих процесів $є$ актуальним, має теоретичне і практичне значення. Крім того, соціально-трудові відносини й відносини власності, що ґрунтуються на демонополізації та приватизації аграрної економіки, забезпечують для сільського населення свободу вибору у сфері зайнятості, самостійне визначення видів і фрорм трудової діяльності.

Логічним продовженням вказаної тенденції $€$ масштабне вивільнення сільських працівників на тлі безпрецедентного посилення ролі соціально-психологічних чинників зайнятості, забезпечення виробництва сучасними технічними засобами. Отже, досягнення продуктивної зайнятості населення як фундаменту i, водночас, важливого показника соціальної орієнтованості сучасного ринкового аграрного господарства $\epsilon$ можливим за умови здійснення соціальної відповідальності, використання засобів малої механізації, що має виробничо-економічне, соціально-культурне і морально-етичне значення для розвитку фермерських та особистих господарств населення.

Аналіз основних досліджень та публікацій. Вагомий науковий внесок у вивчення використання трудових ресурсів, проблем зайнятості сільського населення, сільського способу життя, підвищення ефективності праці зробили такі відомі науковці: О. А. Бугуцький, В. С. Дієсперов, Г.І. Купалова, Е. М. Лібанова, В.ІІ Лишиленко, М. П. Поліщук, І. А. Романюк, К. І. Якуба та ін. Особливості аграрного виробництва, функціонування фермерських і особистих селянських господарств досліджували С Ю. Кучеренко, Л. Ю. Леваєва, Ю. О. Лупенко, М. Й. Малік, Л. О. Мармуль, В. С. Петренко, Н.В.Рунчева, Р. М. Шмідт та інші науковці. У їх роботах вагоме значення надається обґрунтуванню й розробці механізмів функціонування фермерських і особистих господарств населення, визначенню рівня їх розвитку, спеціалізації й розміщення виробництва, управління ним. Однак встановлення ресурсного потенціалу їх функціонування й розвитку потребує поглиблених досліджень.

Мета статті. Метою статті $є$ виявлення чинників фрормування і рівня та використання трудового й виробничого потенціалу фермерських та особистих господарств населення, а також обґрунтування на цій основі напрямів його удосконалення й управління розвитком на перспективу.

Виклад основного матеріалу дослідження. Земельна реформа відкрила шлях до радикальних змін у системі соціально-економічних відносин на селі. А саме, дала змогу селянам приєднувати земельні паї до своїх земельних ділянок з метою формування фермерських та збільшення потенціалу особистих селянських господарств. За результатами опитування $81,4 \%$ респондентів - сільських жителів є власниками земельного паю. Але, не дивлячись на те, що більшість селян отримали земельні паї, обробити їх вони не в змозі, оскільки розпаювання землі значно випередило паювання майна колективних сільськогосподарських підприємств.

Тому переважна більшість нових землевласників виявилася без сільськогосподарської техніки, не згадуючи вже про інші засоби виробництва, без яких неможливо розпочати самостійне господарювання. Залишається одне - здавати землю в оренду. Так, у ході здійсненого обстеження фермерських і особистих господарств населення у Херсонській області (обсяг вибірки - 320 господарств у 6 населених пунктах 3 кількістю 500,0-1000,0 дворів) 3'ясувалось, що 74,9\% респондентів здали свої земельні паї в оренду і лише від 2,7\% до 10,0\% приєднали земельні ділянки до особистого господарства і обробляють їх самостійно [1]. Необхідно відмітити, що більшість селян здали свої паї підприємству, де вони працюють або працювали (84,4\%), а селянському (фермерському) господарству й іншому господарю, - лише від 3,1 до 11,7\%.

Як показують дослідження, на сьогодні значна частина селян не має можливості організувати юридичні суб'єкти власного господарювання, що зумовлено рядом об'єктивних і суб'єктивних чинників. Так, згідно обстеження станом на 1 січня 2019 р. один трактор мала кожна 7 сім'я; вантажний автомобіль - кожна 18; легковий автомобіль - кожна 2; мотоцикл - кожна 3; мотоблок - кожна 15. Це не дає змогу сільським мешканцям здійснювати широку підприємницьку діяльність, тому спонукає селян займатись особистим господарством перш за все для одержання додаткових доходів, зверх основної їх діяльності на стороні, без створення юридичної особи. Отже, виробничі ресурси ОСГ мають значні резерви й мотиви для покращення.

Як відомо, основним джерелом нарощування виробництва сільськогосподарської продукції є ефективне використання землі [2, с. 24]. Тому заслуговує позитивної оцінки бажання власників особистих селянських господарств підвищувати родючість ґрунту у своєму господарстві. Так, за даними анкетного опитування, лише 14,6\% респондентів оцінюють рівень родючості ґрунту своєї земельної ділянки як високий і вище середнього, 73,6\% - середній, 10,3\% - нижче середнього і 1,5\% - дуже низький, земля виснажена. Важливо, що 50,0\% респондентів бажають в повній мірі, а 49,0\% - частково відновлювати родючість ґрунту в своєму господарстві, використовуючи власні органічні добрива (79,4\% респондентів), при додатковому придбанні і внесенні в ґрунт мінеральних добрив (17,8\%), дотримуючись необхідних агротехнічних прийомів (17,6-20,1\%). 
Однак особливості даної форми господарювання, її параметри, вплив зовнішнього середовища формують передумови та створюють специфічні проблеми, властиві саме такому типу господарств. У результаті проведеного нами опитування були виявлені фактори, що обмежують розмір землекористування особистих селянських господарств. Серед основних причин респонденти виділяють такі: використання ручної праці - 50,0\%, мала забезпеченість засобами механізації - 36,6\% і не вистачає робочої сили - 28,1\%. Інші варіанти відповідей не набрали відчутної кількості голосів.

Не дивлячись на розвиток науково-технічного прогресу, низький рівень матеріально-технічної бази в аналізованих господарствах призводить до великих трудових затрат, а це, в свою чергу, не дозволяє населенню значно розширювати посівні площі. Для зайнятих в особистих селянських господарствах характерний високий рівень самоексплуатації при виробництві трудомісткої сільськогосподарської продукції [3, с. 114]. Селяни організують діяльність у своїх особистих господарствах в основному на ручній праці членів сім'ї. А з розширенням площ обробітку землі цих господарств трудонавантаження на членів сімей відповідно ще зросло, при обмежених ресурсах їх ручної праці.

Тому, як показують дослідження, у більшій частині особистих селянських господарств обмежуючим фактором розвитку виробництва виступає робоча сила, яка при винятково низькому рівні механізації виробничих процесів, служить головною складовою ресурсного потенціалу. Звідси, однією з першочергових задач, яка суттєво впливає на темпи розвитку фермерських і особистих селянських господарств, є зниження трудовитрат при виконанні сільськогосподарських робіт.

Однак, фермерські й особисті селянські господарства мають потребу не тільки в засобах масової механізації для обробітку своїх присадибних ділянок, а й в широкому наборі технічних засобів для тваринництва і рослинництва, кормо-виробництва і переробки продукції. Існує велика потреба в налагодженні виробництва засобів малої механізації, у збільшенні випуску і поліпшення якості простих знарядь праці. Це обумовлено тим, що основна маса робіт в особистих господарствах ведеться саме із застосуванням звичайних знарядь ручної праці, яких також не вистачає. Відсутність сучасних технічних засобів не тільки заважає полегшенню праці, але і її продуктивності, що тягне за собою негативне ставлення до цього виду праці як до непрестижної, нецікавої в частині сільського населення і, насамперед, у молоді [4, с. 209].

Отже, широке використання засобів малої механізації має велике виробничо-економічне, соціальнокультурне і морально-психологічне значення. Воно дає можливість підвищити продуктивність і культуру праці, зменшити її тривалість і важкість (особливо для жінок і пенсіонерів), справедливо й раціонально розподіляти трудові навантаження між членами сім'ї.

Не зважаючи на виявлені проблеми, сьогодні фермерські й особисті селянські господарства $є$ основними виробниками продукції тваринництва рослинництва, особливо нішевого. Результати дослідження показали, що основними причинами, що спонукали збільшення поголів'я худоби, були: низька зарплата, затримка її виплат або взагалі безробіття - 37,0\%; необхідність розв'язання проблеми забезпечення продуктами харчування - 38,3\%; це стало тепер більш вигідною справою, ніж раніше - 33,6\%; доступність кормових ресурсів - 17,6\%.

Серед причин, які перешкоджають збільшенню поголів'я тварин, сільські жителі особливо виділяють такі: важка щоденна робота - 54,7\%; відсутність кормів і труднощі з їхнім придбанням (36,9\%); велика частка ручної праці (32,9\%); труднощі із забезпеченням теплими спеціалізованими приміщеннями (11,1\%) та інші. Безумовно, рівень затрат праці і працемісткість виконання робіт по обслуговуванню худоби залежать від забезпеченості особистих селянських господарств необхідними засобами механізації.

На жаль, лише 2,5\% селянських господарств із загальної кількості опитаних мають мотоблоки, 0,8\% апарат для доїння і 42,2\% - засоби малої механізації (зернодробарка, корморізка, січкарня). А це не дозволяє більшості з них механізувати роботи по заготівлі кормів, підготовці їх до згодовування і роздачі, доїнню корів, видаленню гною і водозабезпеченню. Проведене дослідження допомогло, певною мірою, також виявити проблеми, які виникають у селян при веденні особистого селянського господарства.

Серед комплексу чинників на перше місце респонденти ставлять постачання кормів (58,0\%), на друге оранку городу (31,9\%), на третє - придбання молодняку (20,6\%), потім надання техніки для перевезення вантажів (15,8\%), придбання садивного матеріалу (12,8\%) і хімічних препаратів захисту рослин $(12,8 \%)$, придбання мінеральних добрив (11,3\%). Слід відмітити, що допомоги в оранці земельного паю, що приєднаний до особистого господарства потребують 1,3\% опитаних, а взагалі ніякої допомоги не потребують при веденні особистого господарства лише 6,0\% сільських жителів.

Як бачимо, однією з основних проблем діяльності особистих селянських господарств, що стримує не тільки ріст поголів'я худоби й домашньої птиці, але і підвищення їхньої продуктивності, є труднощі щодо забезпечення худоби кормами. Особисті селянські господарства відчувають потребу в закріпленні за ними сінокосів і пасовищ з урахуванням поголів'я індивідуальної худоби, у розширенні практики укладання договорів про відвід земель для заготівель кормів у тимчасове користування (на декілька років) населенню у непридатних для вирощування культурних рослин місцях, з умовою приведення їх у порядок - розчищення від чагарників, каменів, піску і т.д. [5].

Станом справ у фермерських та особистих селянських господарствах мають постійно цікавитися агрономи, зоотехніки, ветеринарні працівники. Це вони повинні правильно вибрати сорти, забезпечити їхню найвищу врожайність з урахуванням складу ґрунту й інших можливостей ділянки, визначити види і кількість необхідних добрив, 
оптимальні терміни для їхнього внесення в ґрунт, порадити, як скласти раціони годівлі в інтересах кращого засвоєння худобою і птицею поживних речовин. Вищевказані проблеми знижують трудову підприємницьку активність власників особистих селянських господарств, однак продовольчі й економічні труднощі стимулюють їх розвиток.

Отже, це спонукає створення й діяльність дорадчих служб і надання ними відповідних послуг. Рівень доходів та якість життя населення сільської місцевості безпосередньо залежать від також від стану культурно-освітнього комплексу. Він відіграє важливу роль у формуванні світогляду, піднесенні інтелектуального рівня та професійнокваліфікаційних характеристик працівників [6, с. 203]. Проблеми культурного дозвілля та відпочинку сільських жителів традиційно вирішуються через мережу клубних закладів, бібліотек, кіноустановок. Проте в сучасних умовах дигіталізації всіх сфер життєдіяльності все більшого значення набувають віртуальні соціальні мережі; сучасні торгово-розважальні й оздоровчі комплекси, яких через різні причини на селі вкрай недостатньо.

Також дефіцит фінансово-інвестиційних ресурсів негативно позначається на обслуговуванні, утриманні та розвитку об'єктів соціокультурної сфери. Так, у Херсонській області через скорочення капітальних вкладень будівництво середніх навчальних, дошкільних, лікарняних закладів та будинків культури практично призупинено. У значній частині сіл відсутня найпростіша медико-санітарна допомога. Сільські мешканці іноді не мають змоги задовольнити мінімум своїх соціальних і культурно-освітніх потреб, що зумовлює погіршення загальних умов їх проживання [7, с. 48].

Дослідженнями Л. Мармуль, І. Романюк встановлено, що у сільській місцевості особливо незадовільною $€$ організація медичного, культурного і побутового обслуговування населення. Тому через низький рівень розвитку соціальної сфери на селі дуже мало робочих місць поза аграрним сектором. Вивільненим людям просто нікуди дітися. До того ж мобільність їх, на відміну від міських жителів, низька. Запитуючи респондентів, чи задовольняють їх умови праці, було встановлено, що в основному ними задоволені лише 32,9\% людей, а частково - 35,9\% [8, с. 167$]$.

Серед усіх опитаних незначна частка осіб, яких повністю задовольняє робота соціальної інфраструктури. В основному задовольняють житлові умови 41,7\% респондентів, рівень та якість навчання у школі - 42,5\%. Переважна більшість опитаних відповіла, що її зовсім не задовольняє служба побуту (57,1\%) й умови відпочинку (48,7\%). Торговим обслуговуванням задоволені в основному лише 32,9\% опитаних респондентів. Щодо медичного обслуговування думки сільських жителів розділились: 43,2\% вважають його зовсім незадовільним, а 39,7\% - частково задовільним.

Крім того, 58,3\% опитаних респондентів вважають, що можливість оздоровлення $є$ не задовільною. Робота дошкільних закладів хвилює трохи менше половини опитаних, але їхні голоси щодо оцінки роботи дитячих дошкільних закладів розділились майже рівномірно за варіантами відповідей. Залишається не досить високим рівень благоустрою більшості сіл. Особливо це стосується забезпечення водою (23,6\% респондентів зовсім незадоволені забезпеченням нею). Приблизно аналогічно оцінюють рівень розвитку соціальної сфери на селі і в досліджуваних районах області.

Таким чином, діюча мережа соціально-культурних закладів, що покликана фрізично, духовно і морально формувати життєве середовище сільських мешканців, за своєю потужністю не спроможна виконувати ці функції в той час як від ефективності роботи соціальної інфраструктури залежить якість трудового потенціалу. Трудовий потенціал працівників вищої якості має кращу результативність праці, більш конкурентоспроможний на аграрному ринку. Крім того, розвиток соціальної інфраструктури для сільського населення - це збільшення кількості робочих місць, покращення умов праці та відпочинку селян, умова закріплення трудових ресурсів на селі і забезпечення ними сільського господарства.

Тому про соціальне відродження села має піклуватися все суспільство. Особливо це стосується великих агрохолдингів та агрокорпорацій. Вони є найбільшими користувачами ресурсів, виробниками продовольства, отримувачами доходів та власниками фінансово-інвестиційних джерел. У попередніх дослідженнях нами визначено, що найбільшою мірою вирішенню цього завдання відповідає концепція, механізми та інструменти соціальної відповідальності, державно-приватного партнерства на селі, соціального менеджменту [9, 10].

Опитування власників особистих селянських господарств показало, що життєвий рівень селян знаходиться за межею бідності і потребує з боку держави законодавчо-методичного та фрінансового коригування. Так, відповіді на питання „Яка з оцінок характеризує Ваші доходи?» розподілились наступним чином: грошей достатньо, щоб ні в чому собі не відмовляти - 4,0\% респондентів, грошей достатньо для придбання необхідних продуктів і одягу - 57,8\%, грошей вистачає лише на продукти харчування - 26,1\%, грошей не вистачає навіть на харчування - 12,1\%.

Висновки. У сучасному селі жителі працюють у фермерських та особистих селянських господарствах для забезпечення продовольчих потреб власної родини й додаткових грошових доходів. Для підвищення їх продуктивності необхідним вважаємо удосконалення виробничого й трудового потенціалу. Також велике значення має підтримка та розвиток соціальної та виробничої інфраструктури, альтернативних видів зайнятості, сільських територій загалом. Цьому сприяє діяльність сільських територіальних громад, інших заходів адміністративно-територіальної реформи на селі.

\section{Список використаних джерел:}

1. Статистичний збірник «Сільськогосподарська діяльність населення у Херсонській області у 2018 р.» / Головне управління статистики у Херсонській області. - Херсон, 2019. - 62c. 
2. Важинський Ф. Перспективні напрямки використання трудового потенціалу сільських територій Тернопільської області : науково-аналітична записка. Львів : ДУ «Інститут регіональних досліджень ім. M.І. Долішнього НАН України», 2016. 45 с.

3. Клокар О. О. Підвищення ефрективності відтворення трудових ресурсів сільськогосподарських підприємств. Економіка АПК. 2011. № 10. С. 112-115.

4. Шарко А. І. Методологічні підходи щодо оцінювання трудового потенціалу підприємства. Держава та регіони. 2011. № 2. С. 206-213.

5. Шмідт Р. М. Коментар до Закону України «Про особисте селянське господарство». Сільський час. 2010. 13 червня. С.7

6. Шестакова А. В. Відтворення трудового потенціалу сільського населення на основі концепції «фрлексік'юріті». Вісн. Житомир. нац. агроекол. ун-ту. 2015. № 2 (51), m. 2. С. 198-207.

7. Яворська А. В. Особливості зайнятості та відродження трудового потенціалу. Україна: аспекти праці. 2014. № 6. С. 46-51.

8. Мармуль Л. О., Романюк І. А. Ринок праці та зайнятість населення сільських територій: теорія і практика регулювання: монографрія. Херсон: Айлант, 2015. - 266 с.

9. Іәнатенко М. М. Стратегії та механізми управління розвитком соціальної відповідальності суб'єктів господарювання аграрної сфери економіки: монографія. Херсон: Айлант, 2015. 470 с.

10.Ігнатенко М. М. Проблеми та перспективи підвищення зайнятості сільського населення на засадах соціальної відповідальності агробізнесу. Ефективна економіка. № $12.2015 . \quad$ URL: http://www.economy.nayka.com.ua/?n=12\&y= 2015.

\section{References}

1. Holovne upravlinnya statystyky u Khersons'kiy oblasti (2019). Statystychnyy zbirnyk «Sil's'kohospodars'ka diyal'nist' naselennya u Khersons'kiy oblasti u 2018 r.» [Statistical collection "Agricultural activity of the population in Kherson oblast in 2018»]. Kherson (in Ukr.).

2. Vazhyns'kyy, F. (2016). Perspektyvni napryamky vykorystannya trudovoho potentsialu sil's'kykh terytoriy Ternopil's'koyi oblasti : naukovo-analitychna zapyska [The perspective directions of employment potential of rural territories of the Ternopil region: scientific and analytical note]. L'viv : DU «Instytut rehional'nykh doslidzhen' im. M.I. Dolishn'oho NAN Ukrayiny» (in Ukr.).

3. Klokar, O. O. (2011). Pidvyshchennya efektyvnosti vidtvorennya trudovykh resursiv sil's'kohospodars'kykh pidpryyemstv [Improving the efficiency of reproduction of labor resources of agricultural enterprises]. Ekonomika APK, 10, 112-115(in Ukr.).

4. Sharko, A. I. (2011). Metodolohichni pidkhody shchodo otsinyuvannya trudovoho potentsialu pidpryyemstva [Methodological approaches to the estimation of the labor potential of the enterprise]. Derzhava ta rehiony, 2, 206213 (in Ukr.).

5. Shmidt, R. M. (2010). Komentar do Zakonu Ukrayiny "Pro osobyste selyans'ke hospodarstvo» [Commentary on the Law of Ukraine «On a Private Peasant Farm»]. Sil's'kyy chas, 7 (in Ukr.).

6. Shestakova, A. V. (2015). Vidtvorennya trudovoho potentsialu sil's'koho naselennya na osnovi kontseptsiyi "fleksik"yuriti» [Restoration of the labor potential of the rural population on the basis of the concept of «flexiurite»]. Visn. Zhytomyr. nats. ahroekol. un-tu, 2 (51), 2, 198-207 (in Ukr.).

7. Yavors'ka, A. V. (2014). Osoblyvosti zaynyatosti ta vidrodzhennya trudovoho potentsialu [Peculiarities of Employment and Revival of Labor Potential]. Ukrayina: aspekty pratsi, 6, 46-51 (in Ukr.).

8. Marmul', L. O. \& Romanyuk, I. A. (2015). Rynok pratsi ta zaynyatist' naselennya sil's'kykh terytoriy: teoriya i praktyka rehulyuvannya [Labor market and rural population employment: theory and practice of regulation]. Kherson: Aylant (in Ukr.).

9. Ihnatenko, M. M. (2015). Stratehiyi ta mekhanizmy upravlinnya rozvytkom sotsial'noyi vidpovidal'nosti sub"yektiv hospodaryuvannya ahrarnoyi sfery ekonomiky [Strategies and mechanisms for managing the development of social responsibility of economic entities of the agrarian sector of the economy]. Kherson: Aylant (in Ukr.).

10. Ihnatenko, M. M. (2015). Problemy ta perspektyvy pidvyshchennya zaynyatosti sil's'koho naselennya na zasadakh sotsial'noyi vidpovidal'nosti ahrobiznesu [Problems and prospects of increasing employment of rural population on the basis of social responsibility of agribusiness]. Efektyvna ekonomika, 12. URL: http://www.economy.nayka.com.ua/?n=12\&y=2015 (in Ukr.).

\section{ДАНІ ПРО АВТОРА}

Ігнатенко Микола Миколайович, доктор економічних наук, доцент, завідувач кафедри економіки ДВНЗ «Переяслав-Хмельницький ДПУ імені Григорія Сковороди» вул. Сухомлинського, 30, м. Переяслав-Хмельницький, 08401, Україна e-mail: professorignatenko@ukr.net orcid.org/0000-0002-5713-7951

\section{ДАННЫЕ ОБ АВТОРЕ}

Игнатенко Николай Николаевич, доктор экономических наук, доцент, заведующий кафедрой экономики ГВУЗ «Переяслав-Хмельницкий ГПУ имени Григория Сковороды» 
ул. Сухомлинского, 30, г. Переяслав-Хмельницкий, 08401, Украина

e-mail: professorignatenko@ukr.net

\section{DATA ABOUT THE AUTHOR}

Ignatenko Nikolay Nikolaevich, Doctor of Economics, Associate Professor, Head of the Department of Economics Pereiaslav-Khmelnytsky Hrygorii Skovoroda State Pedagogical University

str. Sukhomlinsky 30, Pereyaslav-Khmelnitsky, 08401, Ukraine

e-mail: professorignatenko@ukr.net

\section{Удк 331.522.4:631.15 \\ https://doi.org/10.31470/2306-546X-2019-40-13-20 \\ ОРГАНІЗАЦІЙНІ ОСОБЛИВОСТІ ФОРМУВАННЯ ТА ВИКОРИСТАННЯ РОБОЧОЇ СИЛИ АГРАРНИХ ПІДПРИЄМСТВ}

Ковтун В. А.

Предметом дослідження є сукупність організаційних особливостей формування та використання робочої сили аграрних підприємств.

Метою роботи є вивчення особливостей організації формування та використання робочої сили аграрних підприємств в умовах ринкової економіки та визначення місця і їі ролі в реалізації стратедії інноваційного розвитку економіки сільського господарства України.

Методологічною основою статmі стали статистико-математичні методи з'ясування чинників особливостей організації робочої сили в аграрних підприємствах, які здійснюється як у процесі їі формування, так і в процесі використання.

Результати роботи. У статmі визначається організаційні особливості формування та використання робочої сили аграрних підприємств, неминучість маситабних змін у структурі та якості робочої сили, що пов'язані зі специфікою аграрного виробництва. Аналізуються організаційні засади формування та використання робочої сили в умовах становлення інноваційних технологічних змін. Значну увагу приділено аналізу природно-економічних та соціальних умов, що вимагають відповідної якості робочої сили та її загальної компетентності, соціально-демографічним характеристикам, які визначають попит та пропозицію на неї.

Галузь застосування результатів, що можуть бути використані у діяльності аграрних підприємств з метою формування робочої сили в умовах оснащення новітньою технікою та підвищення рівня механізації, електрифікації й автоматизації основних трудових процесів, а також зі зміною трудомісткості виробництва аграрної продукції, що супроводжується підвищеним попитом на робочу силу, аніж на засоби виробництва

Висновки. Формування ефективного робочого потенціалу в аграрних підприємствах передбачає організаційні та соціально-економічні особливості, які передбачають ефективне їх використання, застосування матеріальних стимулів та соціально орієнтованих мотиваційних механізмів, які дозволять підвищити показники продуктивності використання робочої сили. Найефективніший шлях підвищення рівня використання робочої сили та показників продуктивності праці є дійова підтримка розвитку високопродуктивного аграрного виробництва і бізнесу, а також коригування структур економіки у напрямі розширення споживчих галузей та сфери послуг. Ця проблема є комплексною і вимагає впровадження на рівні держави та здійснення цілісної системи заходів правового, економічного, соціального, медичного, освітнього, культурного, організаційного та природоохоронного характеру.

Ключові слова: організація, сільське господарство, аграрні підприємства, робоча сила, особливості формування та використання робочої сили.

\section{ОРГАНИЗАЦИОННЫЕ ОСОБЕННОСТИ ФОРМИРОВАНИЯ И ИСПОЛЬЗОВАНИЯ РАБОЧЕЙ СИЛЫ АГРАРНЫХ ПРЕДПРИЯТИЙ}

Ковтун В. А.

Предметом исследования является совокупность организационных особенностей фрормирования и использования рабочей силы аграрных предприятий.

Целью работы является изучение особенностей организации фрормирования и использования рабочей силы сельскохозяйственных предприятий в условиях рыночной экономики и определение места и ее роли в реализации стратегии инновационного развития экономики сельского хозяйства Украины.

Методологической основой статьи стали статистико-математические методы выявления факторов особенностей организации рабочей силы в аграрных предприятиях, осуществляется как в процессе ее формирования, так и в процессе использования.

Результаты работы. В статье определяется организационные особенности формирования и использования рабочей силы аграрных предприятий, неизбежность маситабных изменений в структуре и качестве рабочей силы, связанные со спецификой аграрного производства. 